\title{
What are the energy and environmental impacts of adding battery storage to photovoltaics? A generalized life cycle assessment.
}

\author{
Marco Raugei, Enrica Leccisi, Vasilis Fthenakis* \\ Dr. Marco Raugei \\ Oxford Brookes University, Wheatley Campus, OX33 1HX, UK \\ and
}

Center for Life Cycle Analysis, Columbia University, New York, NY 10027, USA

E-mail: marco.raugei@brookes.ac.uk

Dr. Enrica Leccisi

Center for Life Cycle Analysis, Columbia University, New York, NY 10027, USA

E-mail: el2828@columbia.edu

Prof. Vasilis Fthenakis

Center for Life Cycle Analysis, Columbia University, New York, NY 10027, USA

E-mail: vmf5@columbia.edu

Keywords: renewable electricity, photovoltaics, lithium-ion battery, energy storage, LCA.

\begin{abstract}
Renewable electricity generation is intermittent and its large-scale deployment will require some degree of energy storage. Although best assessed at grid level, the incremental energy and environmental impacts of adding the required energy storage capacity may also be calculated specifically for each individual technology. This paper deals with the latter issue for the case of photovoltaics (PV) complemented by lithium-ion battery (LIB) storage. A life cycle assessment (LCA) of a 100MW ground-mounted PV system with 60MW of (lithiummanganese oxide) LIB, under a range of irradiation and storage scenarios, show that energy pay-back time and life-cycle global warming potential increase by $7 \%$ to $30 \%$ (depending on storage duration scenarios), with respect to those of PV without storage. Thus the benefits of PV when displacing conventional thermal electricity (in terms of carbon emissions and energy renewability) are only marginally affected by the addition of energy storage.
\end{abstract}

\section{Introduction}




\section{WILEY-VCH}

Recent years have seen the beginning of a transition from fossil fuels towards alternative sources of energy, and renewable energies have grown significantly worldwide ${ }^{[1]}$. However, the large-scale penetration of renewable electricity in electric grids requires the implementation of energy storage systems because of the intrinsic variability and intermittent profiles associated with renewables ${ }^{[2]}$. Specifically, the electricity produced from renewable energy sources (RES) fluctuates on both short-term (seconds to hours) and long-term scales (months, years ${ }^{[3]}$. However, production and consumption in a power supply system always need to be balanced, and therefore there is a need for reserve power capacities to ensure the security of supply. The latter can be provided in the form of adjustable back-up power plants (operated e.g. on gas) or storage units. Storage units can store surplus electricity generated when the production from RES exceeds the demand and, hence, reduce the need for curtailment of electricity produced from RES ${ }^{[4-5]}$.

Ideally, the impacts associated with storage systems would be assessed at grid level, as discussed in previous studies ${ }^{[6,7,8]}$. However, it is also interesting to quantify the energy and environmental impacts of energy storage systems per se, and to identify how adding them to individual electricity generation technologies affects their energy and environmental performance.

Energy storage systems includes five main families of technologies: electrochemical (batteries), mechanical (pumped hydro, flywheels, and compressed air), chemical (fuel cells and electrolyzers), thermal, and electrical (double layer capacitors, super capacitors, super conducting magnetic loops ${ }^{[9]}$. Currently, the vast majority of grid-level storage capacity is provided by pumped hydro storage (PHS), which has a very long technical lifetime as its main advantage, and its dependence on topographical conditions as its main limitation. In the future, the role of electrochemical, and in particular lithium ion batteries (LIB), storage is expected to grow, also due to the fact that the total installed cost of a LIB in stationary applications could fall from 2016's price of approximately $400 \$ / \mathrm{kWh}$ by an additional $60 \%$ by $2030^{[10]}$. LIB also have other advantages such as rapid charge capability, high energy density, and efficiencies of up to $>90 \%$, without the need of maintenance during operation ${ }^{[9,2]}$. Although there is a plethora of articles on energy storage and LIB in particular, there is a dearth of studies on the environmental and energy impacts of their deployment in association with renewable technologies, and in particular with photovoltaic (PV) systems ${ }^{[11]}$. Hence, the aim of this study is to quantify the energy and environmental performance of ground-mounted PV systems complemented by LIB storage, in comparison to PV systems without storage, using a life-cycle approach. Specifically, this work quantifies such impacts in 


\section{WILEY-VCH}

terms of two key life-cycle impact indicators: global warming potential (GWP), and acidification potential (AP), and two energy performance metrics: non-renewable cumulative energy demand (nr-CED) and energy pay-back time (EPBT). Finally, a comparison is shown, based on GWP and AP, with conventional thermal electricity technologies.

\section{System under study}

The PV system under study was defined as a generalised $100 \mathrm{MW}_{\mathrm{AC}}$ utility-scale groundmounted installation comprising a mix of $65 \%$ multi-crystalline (mc-Si) and $35 \%$ singlecrystalline (sc-Si) silicon technologies. The choice to focus on c-Si was dictated by the latter's sheer prominence on the PV market (93\% of market share by installed power), while the mc$\mathrm{Si} / \mathrm{sc}-\mathrm{Si}$ shares reflect the latest available data on global production ${ }^{[12]}$.

Life-cycle inventory (LCI) data for the PV modules was sourced from the latest published report containing average industry-vetted information ${ }^{[13]}$; in both cases, Chinese production was assumed, which is representative of over $70 \%$ of global production ${ }^{[12]}$. The model for the electricity used for PV module manufacturing was duly adapted based on the Chinese grid mix.

LCI data for the balance of system (BOS, including structural elements as well as electrical components such as cabling and inverters) are from a previous publication ${ }^{[14]}$. $\mathrm{PV}$ module efficiencies were modelled on the basis of the latest reported average efficiencies for commercial modules, namely $16.7 \%$ for $\mathrm{mc}-\mathrm{Si}$ and $18 \%$ for sc- $\mathrm{Si}^{[12]}$. The performance ratio (PR) of today's PV ground-mount utility systems is reported to average at approximately $85 \%{ }^{[9]}$; such value was de-rated here to $80 \%$ in order to account for the effect of degradation ${ }^{[15]}$. Finally, PV system lifetime was set at the recommended industry standard of 30 years ${ }^{[16]}$.

LCI data for the Li-ion batteries were sourced from Ecoinvent $3.5^{[17]}$, which in turn largely relies on a model previously described by Notter et al. ${ }^{[18]}$. Primary (virgin) lithium may be extracted from the geosphere by means of two types of processes: conventional mining of igneous rocks which contain $\mathrm{Li}$-rich crystals, and inspissation of lithium carbonate brines from water bodies that contain it in high concentration. While the former source of $\mathrm{Li}$ is the longest-established one, since the 1980s more and more large-scale lithium brine operations have become commercially active in South America; therefore, the lithium used for the cathode of the LIB analysed here was assumed to be sourced from Chilean concentrated brines. Battery cell production was then assumed to take place in China, which is home to $73 \%$ of the world manufacturing capacity ${ }^{[19]}$, and once again the corresponding electricity input was modelled based on the Chinese grid mix. 


\section{WILEY-VCH}

Lithium manganese oxide (LMO) was chosen as the reference cathode chemistry since it is among the most mature options for LIBs. In fact, while it lags behind somewhat in terms of energy density ( $114 \mathrm{Wh} / \mathrm{kg}$ vs. up to $250 \mathrm{Wh} / \mathrm{kg}$ for some Co-rich alternatives ${ }^{[20,21]}$ ), it is still a viable option for large-scale storage due to its comparatively long cycle life, its overall stability, and its reliance on abundant and eco-friendly materials ${ }^{[20]}$.

By way of sensitivity analysis, the life-cycle impact results for the PV+storage system were then also recalculated by using the impact metrics per $\mathrm{kWh}$ of LIB storage reported by two recent and well-documented literature studies for nickel-cobalt-manganese $(\mathrm{NCM}){ }^{[22]}$ and for lithium-iron phosphate (LFP) Li-ion battery packs ${ }^{[23]}$.

The round-trip storage efficiency was assumed to be $80 \%$, a value in the middle of the reported range for LIBs $^{[24]}$, and consistent with previous literature estimates ${ }^{[25]}$.

Figure 1 illustrates a typical daily cycle of PV electricity production, and the share of which (identified as Region II) that may be routed into storage.

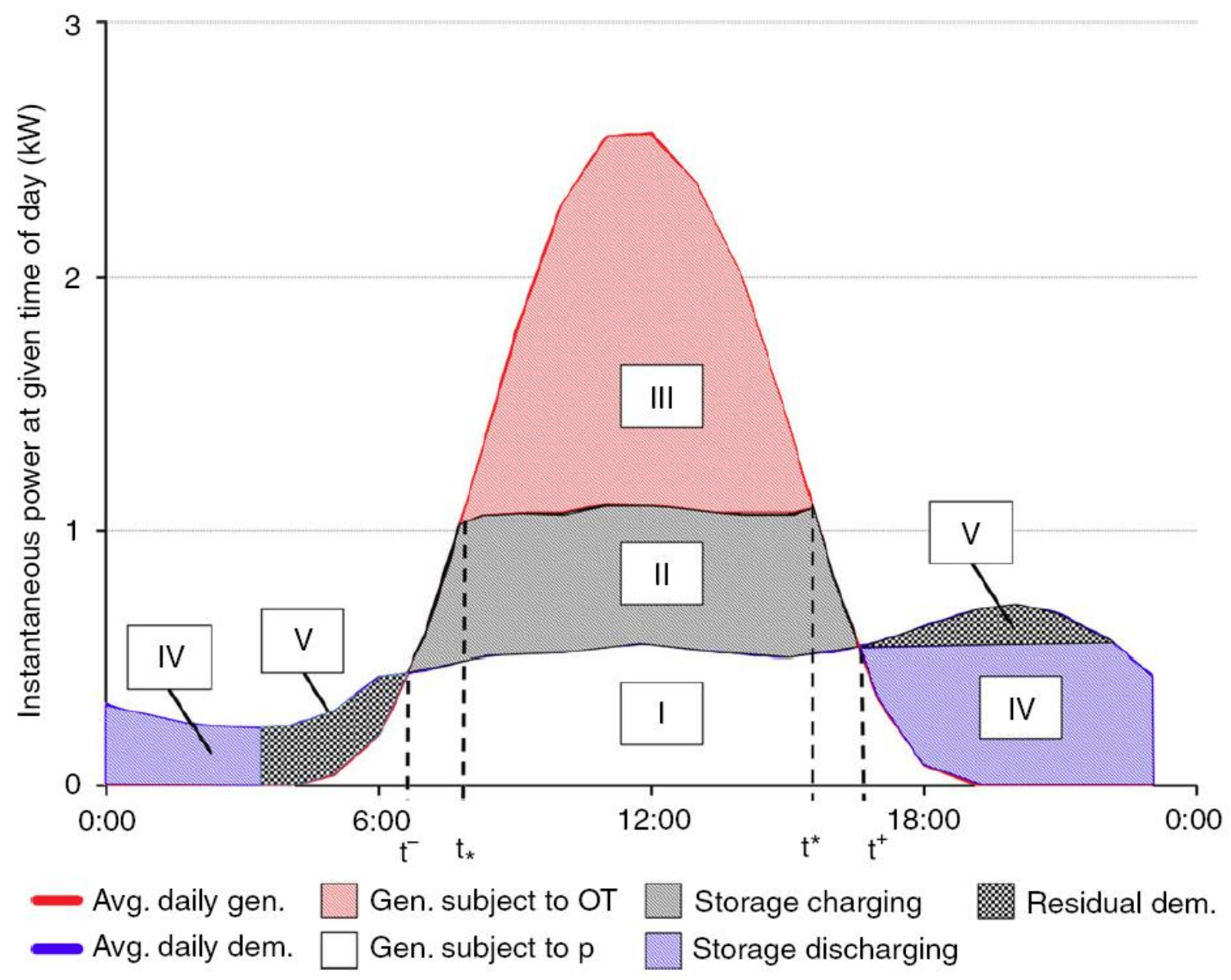

Figure 1. Pattern of daily charging and discharging of a battery supplementing a PV system. Region I represents self-consumption from solar generation; region II is surplus energy that can be stored and subsequently discharged as region IV (minus efficiency losses); and Region III is surplus energy sold to the grid (possibly at overage tariff $=\mathrm{OT}$ ). Region V is 


\section{WILEY-VCH}

residual demand that would not be met by the battery and must be met through purchases from the grid (not considered here) at retail rate $p$. Reproduced with permission. ${ }^{[2]} 2019$, Nature Publishing Group.

The first key parameter for the PV+storage model is the maximum amount of LIB storage capacity per charge cycle. This was initially set as 4 hours of storage capacity at $60 \mathrm{MW}$ maximum battery power ${ }^{1}$, thus $240 \mathrm{MWh}$ of electricity storage per charge cycle, based on a typical example application reported by the US National Renewable Energy Laboratory ${ }^{[27,28]}$. The resulting $240 \mathrm{MWh}$ of electrical storage could then be deployed in a number of ways, depending on demand (e.g., $30 \mathrm{MW}$ for $8 \mathrm{~h}, 15 \mathrm{MW}$ for $16 \mathrm{~h}$, etc.). The second key parameter for the $\mathrm{PV}+$ storage model is the overall share of the total electricity produced by the PV system over its full service life that ends up being routed into LIB storage; this share depends on the specific location and demand profile.

In order to capture the inherent variability of a number of possible PV+storage scenarios, we therefore subjected the two aforementioned key model parameters, namely the hours of storage capacity per charge cycle and the $\%$ of total PV electricity stored, to a halving-anddoubling sensitivity analysis, thereby defining three $\mathrm{PV}+$ storage scenarios: "minimum storage" ( 2 hours of storage capacity at $60 \mathrm{MW}, 7.5 \%$ of total PV electricity stored), "baseline" (4 hours of storage capacity at $60 \mathrm{MW}, 15 \%$ of total PV electricity stored) and "maximum storage" ( 8 hours of storage capacity at $60 \mathrm{MW}, 30 \%$ of total PV electricity stored). All the calculations were repeated three times for three typical solar irradiation levels of interest, namely: $1,000 \mathrm{kWh} \cdot \mathrm{m}^{-2} \cdot \mathrm{yr}^{-1}$ (representative of low solar resource availability regions like, e.g., the UK), $1,700 \mathrm{kWh} \cdot \mathrm{m}^{-2} \cdot \mathrm{yr}^{-1}$ (representative of medium solar resource availability regions like, e.g., southern Europe and New York in the USA), and 2,300 $\mathrm{kWh} \cdot \mathrm{m}^{-2} \cdot \mathrm{yr}^{-1}$ (representative of high solar resource availability regions like, e.g., Arizona in the USA). LIB life expectancy was also investigated, but it was found not to be critical. The literature reports that, setting a conservative maximum allowable $20 \%$ reduction in depth of discharge (which may unacceptable for EVs, but which is still perfectly tolerable for stationary applications), a typical LMO LIB can undergo over 7,000 full charge-and-discharge cycles ${ }^{[29]}$. As shown in Tables 1-3, this number of cycles is much larger than that required by the $\mathrm{PV}+$ storage scenarios considered here, even under high irradiation conditions $\left(2,300 \mathrm{kWh} \cdot \mathrm{m}^{-}\right.$

\footnotetext{
${ }^{1}$ For a $100-\mathrm{MW}$ PV system with an inverter loading ratio $=1.3$, the inverter size must be $77 \mathrm{MW}$ AC $(100$ $\mathrm{MW} / 1.3)$. Using the inverter/storage size ratio (1.67) suggested in Denholm et al. ${ }^{[26]}$, the storage power capacity must be $46 \mathrm{MW}$ AC (77/1.67). Thus, to match a 100-MW PV system, the storage power capacity must be 60 MW DC $(46 \times 1.3)$.
} 


\section{WILEY-VCH}

$\left.{ }^{2} \cdot \mathrm{yr}^{-1}\right)$. In other words, in no circumstances is there a need to replace the battery pack before the planned end of the PV system's service life.

Finally, while it may be argued that the results presented here for the various PV scenarios would change (and likely worsen) in the event that grid management dictated that a share of the PV electricity be curtailed, at the same time, it is also reasonable to assume that, on a large scale, not all storage capacity would be provided by Li-ion batteries, but that, instead, considerably lower-impact alternatives (among which often pumped hydro) would play a significant role. Therefore, including curtailment and other storage technologies as additional variables would only be appropriate if at the same time the goal and scope of the study were shifted from the generalized assessment of the energy and environmental performance of PV electricity taken in isolation, to that of a whole grid mix under a specific set of conditions. Assessments of this latter type have been made before ${ }^{[6,7,8]}$ and will be the object of further investigation in the future, but fall outside the intended remit of this paper.

- Table 1 HERE -

- Table 2 HERE -

- Table 3 HERE -

\section{Methods}

The analysis was carried out in adherence to ISO standards $14040^{[30]}$ and $14044^{[31]}$ for life cycle assessment (LCA). The functional unit of analysis was set as $1 \mathrm{kWh}$ of electricity delivered by the ground mounted PV + Li-ion battery storage system. The system boundary comprises all supply chain processes required for the extraction, processing, and delivery of the required materials and energy carriers over the system manufacturing and use phases. The end-of-life (EoL) phase was not included, due to a lack of detailed inventory information, largely because these systems have not yet reached the critical mass required for economical large-scale take-back and recycling. It has been pointed out in the literature that, for both PV and Li-ion battery systems, large-scale material recycling could actually provide significant environmental (as well as economic) benefits ${ }^{[32,33,34,35]}$. Based on these preliminary findings, it may be expected that EoL treatment would not result in a worsening of the 'cradle-to-grave' energy and environmental performance indicators calculated here. Nonetheless, this remains an open subject for future investigation.

All background processes (i.e., those for the supply chains of glass, steel, aluminium, and all other material and energy inputs required by the analysed systems at the foreground level) 


\section{WILEY-VCH}

were modelled on the basis of the information provided in the globally accepted Ecoinvent v3.5 LCI database ${ }^{[17]}$.

In terms environmental impacts, the focus was set on two prominent impact categories, namely global warming potential (GWP), and acidification potential (AP), both assessed at mid-point level using the widely-adopted CML life cycle impact assessment (LCIA) method $^{[36]}$.

This was complemented by a thorough assessment of the total non-renewable primary energy harvested from the environment over the full life cycle of the analysed system, resulting in the non-renewable cumulative energy demand (nr-CED) indicator ${ }^{[37,38]}$. Also, the often-reported energy pay-back time (EPBT) metric was also calculated, as per Equation 1:

$\mathrm{EPBT}[\mathrm{yr}]=\mathrm{CED} /\left(\mathrm{Out}_{\mathrm{el}, \mathrm{yr}} / \eta_{\mathrm{G}}\right)$

Where:

$\mathrm{CED}=$ total (renewable + non-renewable) cumulative primary energy demand for the (100MW PV + $60 \mathrm{MW}$ storage) system (excluding the renewable solar energy harvested during the use phase) $[\mathrm{MJ}]$

Out $_{\mathrm{el}, \mathrm{yr}}=$ average electricity delivered by the (100MW PV $+60 \mathrm{MW}$ storage) system over the course of one year of its service life $\left[\mathrm{MJ} \cdot \mathrm{yr}^{-1}\right]$

$\eta_{\mathrm{G}}=$ life-cycle energy efficiency (from primary energy harvested to electricity delivered) of the grid mix into which the $(100 \mathrm{MW} \mathrm{PV}+60 \mathrm{MW}$ storage $)$ system is embedded $\left(\eta_{\mathrm{G}}=0.3\right.$ is assumed here).

\section{Results and discussion}

Table 4 reports all comparative values of the selected environmental performance indicators for the PV system with no energy storage (and without curtailment), and for the PV+storage scenarios under "baseline", "minimum storage" and "maximum storage" conditions, respectively in terms of GWP and AP per kWh of electricity delivered. The PV+storage results are calculated three times, alternatively assuming the use of three different Li-ion battery chemistries: LMO (reference case) ${ }^{[17]}$, NMC ${ }^{[22]}$ and LFP $^{[23]}$.

Under "baseline" conditions, and assuming the use of LMO batteries, the GWP and AP for the PV+LIB storage system respectively worsen by $14 \%$ and $19 \%$ with respect to the "PV only" scenario. At worst, when considering the "maximum storage" scenario with $8 \mathrm{~h}$ of storage, as much as $30 \%$ of the total electricity produced by the PV system over its lifetime 


\section{WILEY-VCH}

being routed into storage, and the use of alternative battery chemistries, the following changes are observed relative to the "PV only" scenario: GWP increases by $+65 \%$ (using NCM batteries) or $+92 \%$ (using LFP batteries), and AP increases by $+71 \%$ (using NCM batteries), or $+48 \%$ (using LFP batteries). Incidentally, these results indicate a trade-off between the alternative LIB technologies, in that while LFP is the most carbon intensive chemistry per $\mathrm{kWh}, \mathrm{NCM}$ is the one that entails the largest acidic emissions.

It is important to note that such results are not to be interpreted as a ceteris paribus comparison of the same 100MW PV system, alternatively "with" or "without" storage, while in both cases deployed in the exact same grid mix. Such a comparison would be incorrect, because if a PV system installed in a specific grid mix actually does requires a certain amount of storage in order to be a viable contributor to the local electricity supply, removing such storage capacity would result in sub-optimal conditions (e.g., leading to the need to curtail peak PV electricity production), and as a result the "PV only" system would end up producing less electricity over its full service lifetime, with detrimental effects on its environmental indicators per functional unit ${ }^{[39]}$. Instead, the correct interpretation of the results presented hereinafter is as a comparison of the energy and environmental performance of a 100MW PV system when deployed in a grid mix with a comparatively low penetration of variable renewable energies (VRE), under which conditions battery storage is not required, vs. the same PV system but deployed in a different (and possibly, future) grid mix characterized by a higher penetration of VRE, in which storage is required.

Figures 2 and 3 then respectively show the GWP and AP indicators for the same range of PV systems (limited for clarity to the use case of LMO batteries only), and contrasted against two typical "peaker" power plants used for grid balancing, namely $10 \mathrm{MW}$ diesel generators (DG) and $10 \mathrm{MW}$ single cycle gas turbines (SCGT), as well as two modern baseload thermal technologies, namely combined cycle gas turbines (NGCC) and hard coal power plants - all based on average global data from Ecoinvent ${ }^{[17]}$. The latter two technologies were chosen as representative of the mainstream technologies which, in the event of a major energy transition, could soon be supplemented and then gradually replaced by the large-scale deployment of renewables (and PV in particular) plus energy storage.

Broadly speaking, results for all conventional thermal generators invariably indicate over one order of magnitude higher greenhouse gas emissions (GWP) per kWh generated with respect to all PV systems, regardless of the amount of storage or the type of LIB. Acidic emissions (AP), mainly $\mathrm{SO}_{2}$ and $\mathrm{NO}_{\mathrm{x}}$, from gas-fired electricity are of the same order of magnitude as those from PVs, with NGCC results actually somewhat lower (depending on solar irradiation 


\section{WILEY-VCH}

and amount of storage), and "peaker" SCGT higher; AP results from both diesel- and coalfired electricity are instead once again one order of magnitude higher.

Moving on to the energy analysis, both the nr-CED (Figure 4) and EPBT (Figure 5) metrics indicate predicted increases from $+9 \%$ ("minimum storage" scenario) to $+18 \%$ ("baseline" storage scenario) to $+36 \%$ ("maximum storage" scenario), compared to the PV system on its own. Considering a typical expected lifetime of 30 years for a modern PV system, these results prove that the addition of Li-ion storage capacity does not in any way render PV electricity not worthy to be pursued, since even under the most unfavourable conditions of combined high storage requirement (480 MWh capacity and 30\% of total electricity stored) and low irradiation $\left(1,000 \mathrm{kWh} \cdot \mathrm{m}^{-2} \cdot \mathrm{yr}^{-1}\right)$, the $\mathrm{PV}+$ storage system would still start delivering net energy after a mere $10 \%$ of its service lifetime.

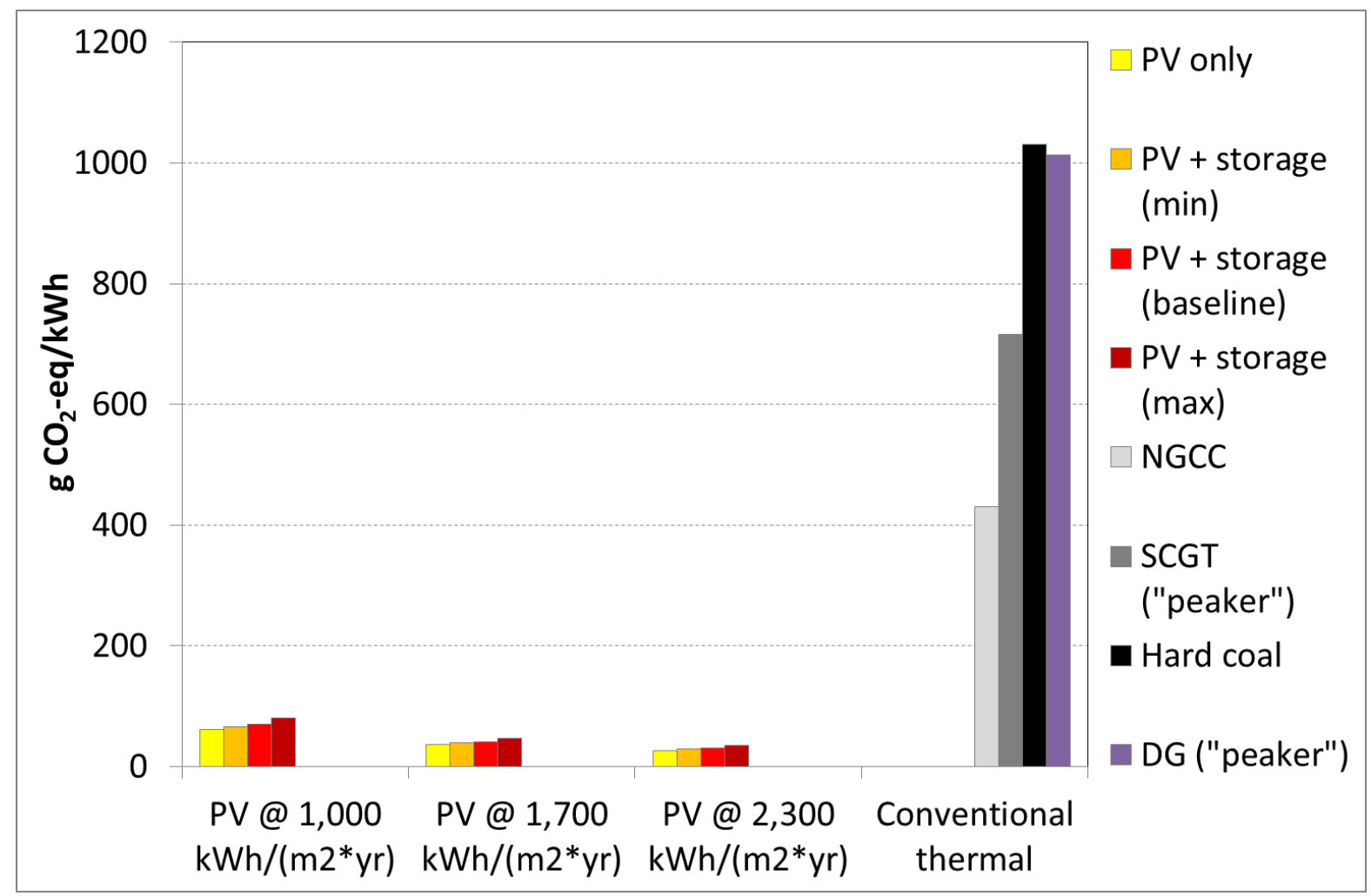

Figure 2. Global Warming Potential (GWP) per kWh of delivered electricity at three different solar irradiation levels.

$\mathrm{PV}$ only $=100 \mathrm{MW}$ ground-mounted PV system (65\% mc-Si / 35\% sc-Si);

$\mathrm{PV}+$ storage $(\mathrm{min})=\mathrm{PV}$ system plus $2 \mathrm{~h}$ of $60 \mathrm{MW}$ Li-ion battery storage, with $7.5 \%$ of total PV electricity stored;

$\mathrm{PV}+$ storage $($ baseline $)=\mathrm{PV}$ system plus $4 \mathrm{~h}$ of $60 \mathrm{MW}$ Li-ion battery storage, with $15 \%$ of total PV electricity stored;

$\mathrm{PV}+$ storage $(\max )=\mathrm{PV}$ system plus $8 \mathrm{~h}$ of $60 \mathrm{MW}$ Li-ion battery storage, with $30 \%$ of total PV electricity stored;

NGCC $=$ Natural gas combined cycles;

SCGT = Single cycle gas turbines ("peaker" technology); 
$\mathrm{DG}=$ Diesel generators ("peaker" technology).

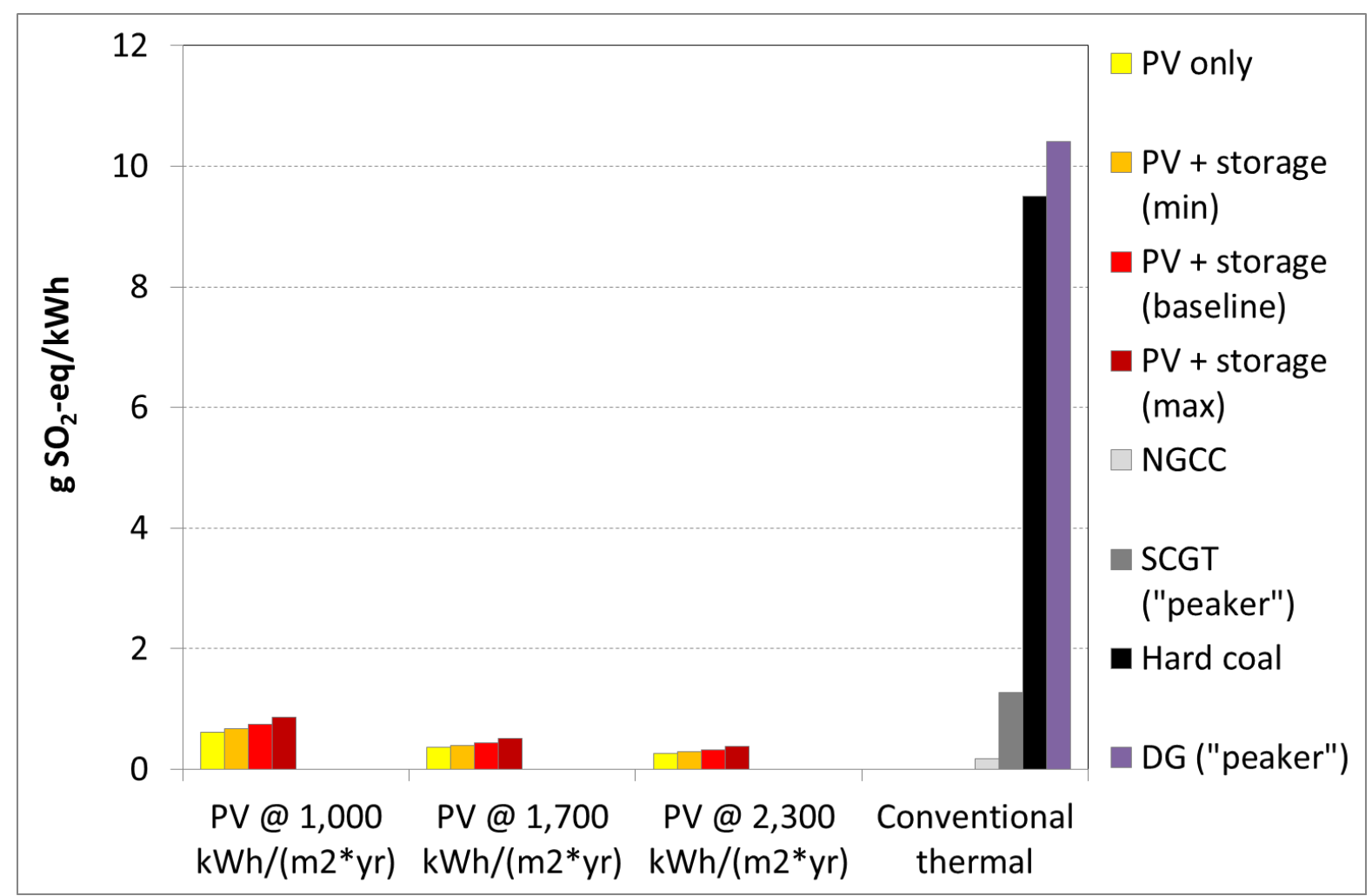

Figure 3. Acidification Potential (AP) per $\mathrm{kWh}$ of delivered electricity at three different solar irradiation levels.

$\mathrm{PV}$ only $=100 \mathrm{MW}$ ground-mounted PV system (65\% mc-Si / 35\% sc-Si);

$\mathrm{PV}+$ storage $(\mathrm{min})=\mathrm{PV}$ system plus $2 \mathrm{~h}$ of $60 \mathrm{MW}$ Li-ion battery storage, with $7.5 \%$ of total PV electricity stored;

$\mathrm{PV}+$ storage $($ baseline $)=\mathrm{PV}$ system plus $4 \mathrm{~h}$ of $60 \mathrm{MW}$ Li-ion battery storage, with $15 \%$ of total PV electricity stored;

$\mathrm{PV}+$ storage $(\max )=\mathrm{PV}$ system plus $8 \mathrm{~h}$ of $60 \mathrm{MW}$ Li-ion battery storage, with $30 \%$ of total PV electricity stored;

NGCC $=$ Natural gas combined cycles;

SCGT = Single cycle gas turbines ("peaker" technology);

$\mathrm{DG}=$ Diesel generators ("peaker" technology). 


\section{WILEY-VCH}

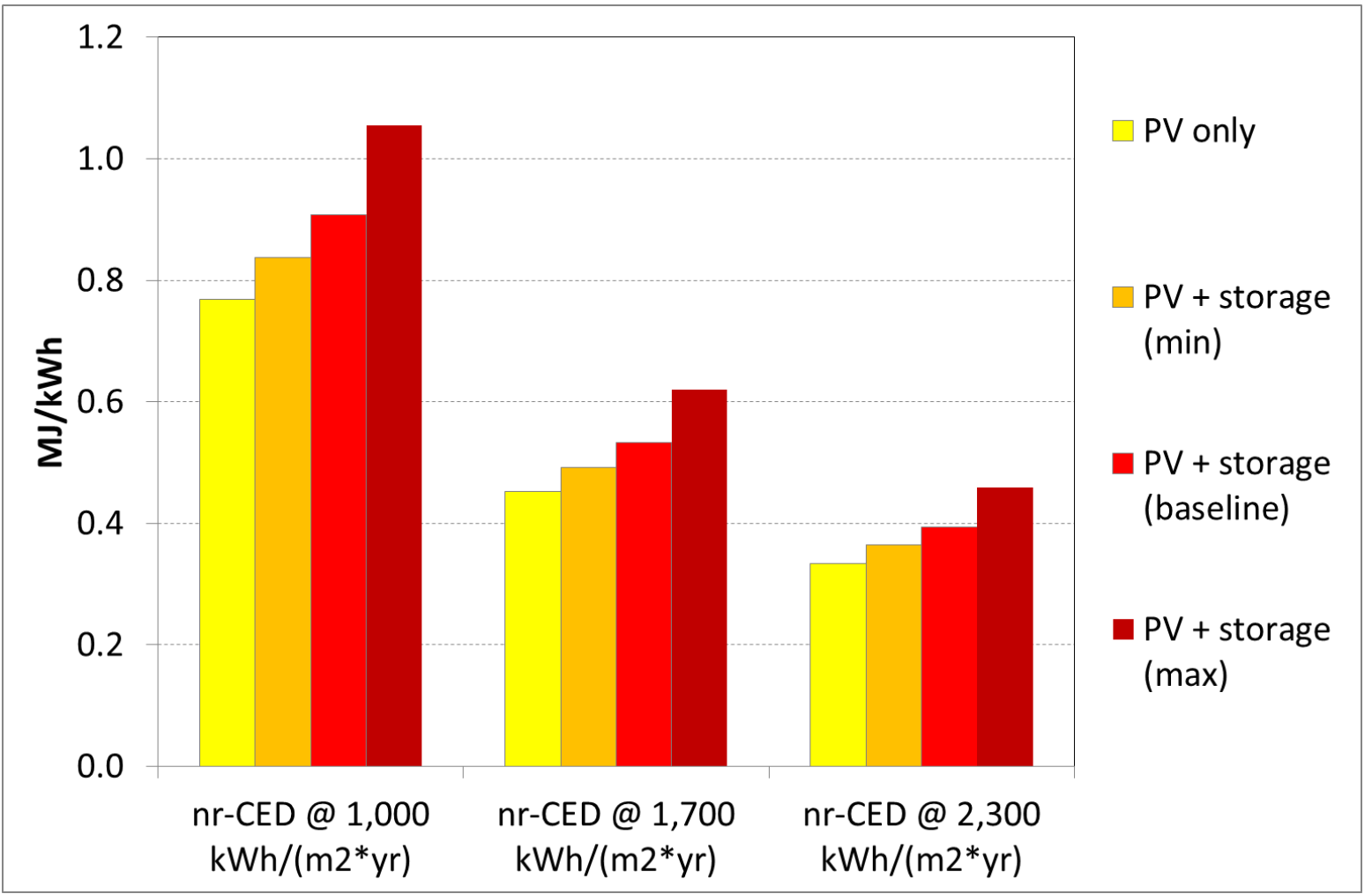

Figure 4. Non-renewable cumulative energy demand (nr-CED) per kWh of delivered electricity at three different solar irradiation levels.

$\mathrm{PV}$ only $=100 \mathrm{MW}$ ground-mounted PV system $(65 \% \mathrm{mc}-\mathrm{Si} / 35 \% \mathrm{sc}-\mathrm{Si})$;

$\mathrm{PV}+$ storage $(\mathrm{min})=\mathrm{PV}$ system plus $2 \mathrm{~h}$ of $60 \mathrm{MW} \mathrm{Li-ion} \mathrm{battery} \mathrm{storage,} \mathrm{with} 7.5 \%$ of total PV electricity stored;

$\mathrm{PV}+$ storage $($ baseline $)=\mathrm{PV}$ system plus $4 \mathrm{~h}$ of $60 \mathrm{MW}$ Li-ion battery storage, with $15 \%$ of total PV electricity stored;

$\mathrm{PV}+$ storage $(\max )=\mathrm{PV}$ system plus $8 \mathrm{~h}$ of $60 \mathrm{MW}$ Li-ion battery storage, with $30 \%$ of total PV electricity stored. 
WILEY-VCH

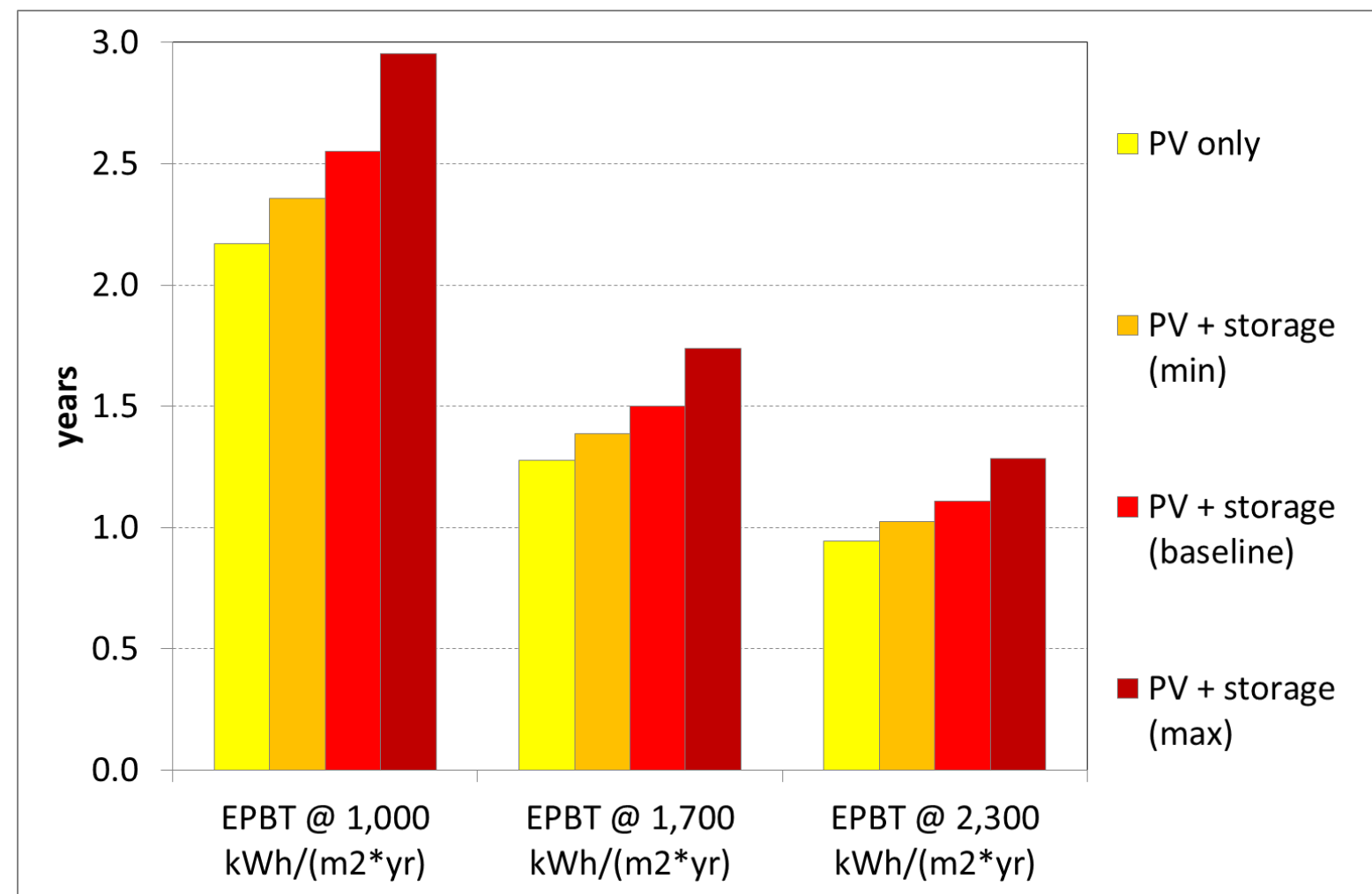

Figure 5. Energy Pay-Back Time (EPBT) at three different solar irradiation levels. $\mathrm{PV}$ only $=100 \mathrm{MW}$ ground-mounted PV system (65\% mc-Si / 35\% sc-Si);

$\mathrm{PV}+$ storage $(\mathrm{min})=\mathrm{PV}$ system plus $2 \mathrm{~h}$ of $60 \mathrm{MW}$ Li-ion battery storage, with $7.5 \%$ of total PV electricity stored;

$\mathrm{PV}+$ storage $($ baseline $)=\mathrm{PV}$ system plus $4 \mathrm{~h}$ of $60 \mathrm{MW}$ Li-ion battery storage, with $15 \%$ of total PV electricity stored;

$\mathrm{PV}+$ storage $(\max )=\mathrm{PV}$ system plus $8 \mathrm{~h}$ of $60 \mathrm{MW}$ Li-ion battery storage, with $30 \%$ of total PV electricity stored.

Assumed grid mix life-cycle energy efficiency $=0.30$.

\section{Conclusion}

A comprehensive life cycle assessment of a typical contemporary ground-mounted c-Si PV installation has demonstrated that, from the points of view of carbon emissions, energy renewability and net energy performance, PV's considerable advantages over all conventional thermal power generators may be expected to remain unaffected by the deployment of even substantial amounts of electrochemical (LIB) storage. PV's reduced life-cycle acidic emissions with respect to coal-fired and "peaker" generators is also maintained, irrespective of the amount of energy storage deployed. It is concluded that adding LIB storage to photovoltaics does not significantly detract from their overall sustainability. Further research could then involve more detailed analyses, in which the hourly electricity supply and demand profiles of well-defined geographical regions are taken into account. This would introduce more specific constraints on PV and other variable renewable energy (VRE) generators, and 


\section{WILEY-VCH}

allow an accurate determination of the actual amounts of storage required in each case to optimize load matching and minimize curtailment; in so doing, the need for a range of scenarios in the quantification of the resulting environmental impacts (of PV as well as entire grid mix) would be side-stepped.

\section{Acknowledgements}

The authors gratefully acknowledge the supply of up-to-date inventory information on PV balance-of-system components by First Solar, inc.

Marco Raugei wishes to acknowledge the financial support provided by the UK EPSRC / Faraday Institution research project 'Recycling of Lithium-ion Batteries (ReLIB)'. Marco Raugei did the LCA modelling of the LIB system, combined the PV and LIB results, and wrote most of the manuscript; Enrica Leccisi did the LCA modelling of the PV system and contributed the introduction to the manuscript; Vasilis Fthenakis guided and refined the PV LCA, outlined the current research aims, and reviewed the calculations and manuscript.

Received: ((will be filled in by the editorial staff))

Revised: ((will be filled in by the editorial staff)) Published online: ((will be filled in by the editorial staff))

\section{References}

[1] IEA, Renewables 2018. Analysis and forecasts to 2023, International Energy Agency, Paris, France, 2018.

[2] D. Lindley, Nature News, 2010, 463(7277), 18.

[3] M. Child, D. Bogdanov, C. Breyer, Energy Procedia, 2018, 155, 44.

[4] I.G. Mason, S. C. Page, A.G. Williamson, Energy Policy, 2010, 38(8), 3973.

[5] N. Kittner, F. Lill, D.M. Kammen, Nature Energy, 2017, 2(9), 17125.

[6] M. Raugei, E. Leccisi, B. Azzopardi, C. Jones, P. Gilbert, L. Zhang Y. Zhou, S.

Mander, P. Mancarella, Energy Policy, 2018, 114, 51.

[7] M. Raugei, E. Leccisi, V. Fthenakis, R.E. Moragas, Y. Simsek, Energy, 2018, 162, 659. 


\section{WILEY-VCH}

[8] D.J. Murphy, M. Raugei, Energy Technology, 2020, in press.

[9] O. Palizban, K. Kauhaniemi, Journal of Energy StorageI, 2016, 6, 248.

[10] IRENA, Electricity storage and renewables: costs and markets to 2030, International Renewable Energy Agency, Abu Dhabi, 2017.

[11] C. Jones, V. Peshev, P. Gilbert, S. Mander, Journal of cleaner production, 2017, 167, 447.

[12] Fraunhofer ISE, Photovoltaics Report, Fraunhofer Institute for Solar Energy Systems, Freiburg, Germany, 2019.

[13] R. Frischknecht, R. Itten, P. Sinha, M. de Wild-Scholten, J. Zhang, V. Fthenakis, H.C. Kim, M. Raugei, M. Stucki, Life Cycle Inventories and Life Cycle Assessments of Photovoltaic Systems, Report T12-04:2015, International Energy Agency, Paris, France, 2015.

[14] E. Leccisi, M. Raugei, V. Fthenakis. Energies, 2016, 9(8):622.

[15] D.C. Jordan, S.R. Kurtz, Progress in Photovoltaics: Research and Applications, 2013, 21(1), 12 .

[16] R. Frischknecht, G. Heath, M. Raugei, P. Sinha, M. de Wild-Scholten, V. Fthenakis, H. C. Kim, E. Alsema, M. Held, Methodology Guidelines on Life Cycle Assessment of Photovoltaic Electricity - $3^{\text {rd }}$ Edition, Report T12-08:2016, International Energy Agency, Paris, France, 2016.

[17] Ecoinvent, Life Cycle Inventory Database, http://www.ecoinvent.org, accessed: August, 2019.

[18] D. A. Notter, M. Gauch, R. Widmer, P. Wäger, A. Stamp, R. Zah, H.-J. Althaus, Environmental Science and Technology, 2010, 44(17), 6550.

[19] R. Rapier, Why China Is Dominating Lithium-Ion Battery Production, https://www.forbes.com/sites/rrapier/2019/08/04/why-china-is-dominating-lithium-ionbattery-production/, accessed: September, 2019. 


\section{WILEY-VCH}

[20] G. Zubi, R. Dufo-López, M. Carvalho, G. Pasaoglu, Renewable and Sustainable Energy Reviews, 2018, 89, 292.

[21] T. Placke, R. Kloepsch, S. Dühnen, M. Winter, Journal of Solid State Electrochemistry, 2017, 21(7), 1939.

[22] L.A.-W. Ellingsen, G. Majeau-Bettez, B. Singh, A.K. Srivastava, L.O. Valøen, A.H. Strømman, Journal of Industrial Ecology, 2014, 18(1), 113.

[23] G. Majeau-Bettez, T.R. Hawkins, A.H. Strømman, Environmental Science \& Technology, 2011, 45, 4548.

[24] Center for Sustainable Systems, U.S. Energy Storage Factsheet, Pub. No. CSS15-17, University of Michigan, 2018.

[25] J. Hoppmann, J. Volland, T. S. Schmidt, V. H. Hoffmann, Renewable and Sustainable Energy Reviews, 2014, 39, 1101.

[26] S. Comello, S. Reichelstein, Nature Communications, 2019, 10.

[27] R. Fu, T. Remo, R. Margolis, 2018 U.S. Utility-Scale PhotovoltaicsPlus-Energy Storage System Costs Benchmark, Report NREL/TP-6A20-71714, National Renewable Energy Laboratory, Golden, CO, USA, 2018.

[28] P. Denholm, J. Eichman, R. Margolis, Evaluating the Technical and Economic Performance of PV Plus Storage Power Plants, NREL/TP-6A20-68737, National Renewable Energy Laboratory, Golden, CO, USA, 2017.

[29] B. Xu, A. Oudalov, A. Ulbig, G. Andersson, D. S. Kirschen, IEEE Transactions on Smart Grid, 2016, 9(2), 1131.

[30] ISO, 14040:2006 Environmental Management - Life Cycle Assessment - principles and framework, International Organization for Standardization, 2006.

[31] ISO, 14040:2006 Environmental Management - Life Cycle Assessment - requirements and guidelines, International Organization for Standardization, 2006. 


\section{WILEY-VCH}

[32] F. Corcelli, M. Ripa, E. Leccisi, V. Cigolotti, V. Fiandra, G. Graditi, L: Sannino, M. Tammaro, S. Ulgiati, Ecological Indicators, 2016, 94(3), 37.

[33] J. B. Dunn, L. Gaines, J. Sullivan, M. Q. Wang, Environmental Science and Technology, 2012, 46(22), 12704.

[34] T. Elwert, D. Goldmann, F. Römer, M. Buchert, C. Merz, D. Schueler, J. Sutter, Recycling, 2016, 1(1), 25.

[35] T. P. Hendrickson, O. Kavvada, N. Shah, R. Sathre, C. D. Scown, Environmental Research Letters, 2015, 10(1).

[36] CML, CML-IA Characterisation Factors,

https://www.universiteitleiden.nl/en/research/research-output/science/cml-ia-characterisation-

factors, accessed: August, 2019.

[37] R. Hischier, B. Weidema, H.-J. Althaus, C. Bauer, G. Doka, R. Dones, R.

Frischknecht, S. Hellweg, S. Humbert, N. Jungbluth, T. Köllner, Y. Loerincik, M. Margni, T. Nemecek, Implementation of Life Cycle Impact Assessment Methods. Ecoinvent report No. 3, v2.2, Swiss Centre For Life Cycle Inventories, Dübendorf, Switzerland, 2010.

[38] R. Frischknecht, F. Wyss, S. Busser Knopfel, T. Lutzkendorf, M. Balouktsi, International Journal of Life Cycle Assessment, 2015, 20, 957.

[39] "Environmental Impacts of Utility-Scale Battery Storage in California": A.

Balakrishnan, E. Brutsch, A. Jamis, W. Reyes, M. Strutner, P. Sinha, and R. Geyer in IEEE PVSC (Chicago, USA), 2019. 


\section{WILEY-VCH}

Table 1. Calculation of total electricity produced by $100 \mathrm{MW}$ PV system over its 30-year service life in low solar irradiation conditions $\left(1,000 \mathrm{kWh} \cdot \mathrm{m}^{-2} \cdot \mathrm{yr}^{-1}\right)$, of the share thereof that is routed into LIB storage, and of the number of full LIB charge cycles that are required over the system's 30-year lifetime.

\begin{tabular}{|c|c|c|c|}
\hline & $\begin{array}{l}\text { "mininum } \\
\text { storage" } \\
\text { scenario }\end{array}$ & $\begin{array}{l}\text { "baseline" } \\
\text { scenario }\end{array}$ & $\begin{array}{l}\text { "maximum } \\
\text { storage" } \\
\text { scenario }\end{array}$ \\
\hline $\mathrm{P}_{\mathrm{PV}}=\mathrm{PV}$ installed power $[\mathrm{MW}]$ & 100 & 100 & 100 \\
\hline $\mathrm{T}=\mathrm{PV}$ lifetime $[\mathrm{yr}]$ & 30 & 30 & 30 \\
\hline$P R=P V$ performance ratio & $80 \%$ & $80 \%$ & $80 \%$ \\
\hline Irr = Solar Irradiation $\left[\mathrm{kWh} \mathrm{m}^{-2} \mathrm{yr}^{-1}\right]$ & 1,000 & 1,000 & 1,000 \\
\hline $\begin{array}{l}\mathrm{PV}_{\text {OUT }}=\mathrm{P}_{\mathrm{PV}} \times \operatorname{Irr} \times \mathrm{PR} \times \mathrm{T} \\
=\text { total } \mathrm{PV} \text { output over lifetime }[\mathrm{MWh}]\end{array}$ & $2,400,000$ & $2,400,000$ & $2,400,000$ \\
\hline $\mathrm{P}_{\mathrm{LIB}}=\mathrm{LIB}$ installed maximum power $[\mathrm{MW}]$ & 60 & 60 & 60 \\
\hline $\mathrm{H}=$ max. sustained LIB output at max. power [h] & 2 & 4 & 8 \\
\hline $\mathrm{C}=\mathrm{P}_{\mathrm{LIB}} \times \mathrm{H}=\mathrm{LIB}$ storage capacity per cycle $[\mathrm{MWh}]$ & 120 & 240 & 480 \\
\hline $\begin{array}{l}S=\text { share of total PV output routed into LIB storage } \\
L I B_{\mid N}=P V_{\text {OUT }} \times S\end{array}$ & $7.5 \%$ & $15 \%$ & $30 \%$ \\
\hline$=\mathrm{PV}$ output routed into LIB storage $[\mathrm{MWh}]$ & 180,000 & 360,000 & 720,000 \\
\hline $\begin{array}{l}\text { DIRECT }=\mathrm{PV}_{\text {OUT }}-\mathrm{LIB}_{\text {IN }} \\
=\mathrm{PV} \text { output delivered directly }[\mathrm{MWh}]\end{array}$ & $2,220,000$ & $2,040,000$ & $1,680,000$ \\
\hline$\eta_{s}=$ storage cycle efficiency & $80 \%$ & $80 \%$ & $80 \%$ \\
\hline $\begin{array}{l}\mathrm{LIB}_{\text {OUT }}=\mathrm{LIB}_{\mathrm{IN}} \times \eta_{\mathrm{S}} \\
=\text { electricity delivered by LIB storage [MWh] }\end{array}$ & 144,000 & 288,000 & 576,000 \\
\hline $\mathrm{N}=\mathrm{LIB}_{\mathrm{IN}} / \mathrm{C}=$ number of full charge cycles & 1,500 & 1,500 & 1,500 \\
\hline $\begin{array}{l}\text { SYS }_{\text {OUT }}=\text { DIRECT + LIB OUT } \\
=\text { electricity delivered by PV+storage system [MWh] }\end{array}$ & $2,364,000$ & $2,328,000$ & $2,256,000$ \\
\hline
\end{tabular}




\section{WILEY-VCH}

Table 2. Calculation of total electricity produced by 100 MW PV system over its 30 -year service life in medium solar irradiation conditions $\left(1,700 \mathrm{kWh} \cdot \mathrm{m}^{-2} \cdot \mathrm{yr}^{-1}\right)$, of the share thereof that is routed into LIB storage, and of the number of full LIB charge cycles that are required over the system's 30-year lifetime.

\begin{tabular}{|c|c|c|c|}
\hline & $\begin{array}{l}\text { "mininum } \\
\text { storage" } \\
\text { scenario }\end{array}$ & $\begin{array}{l}\text { "baseline" } \\
\text { scenario }\end{array}$ & $\begin{array}{l}\text { "maximum } \\
\text { storage" } \\
\text { scenario }\end{array}$ \\
\hline $\mathrm{P}_{\mathrm{PV}}=\mathrm{PV}$ installed power $[\mathrm{MW}]$ & 100 & 100 & 100 \\
\hline $\mathrm{T}=\mathrm{PV}$ lifetime $[\mathrm{yr}]$ & 30 & 30 & 30 \\
\hline$P R=P V$ performance ratio & $80 \%$ & $80 \%$ & $80 \%$ \\
\hline Irr = Solar Irradiation $\left[\mathrm{kWh} \mathrm{m}^{-2} \mathrm{yr}^{-1}\right]$ & 1,700 & 1,700 & 1,700 \\
\hline $\begin{array}{l}\mathrm{PV}_{\text {OUT }}=\mathrm{P}_{\mathrm{PV}} \times \operatorname{Irr} \times \mathrm{PR} \times \mathrm{T} \\
=\text { total } \mathrm{PV} \text { output over lifetime }[\mathrm{MWh}]\end{array}$ & $4,080,000$ & $4,080,000$ & $4,080,000$ \\
\hline $\mathrm{P}_{\mathrm{LIB}}=\mathrm{LIB}$ installed maximum power $[\mathrm{MW}]$ & 60 & 60 & 60 \\
\hline $\mathrm{H}=$ max. sustained LIB output at max. power [h] & 2 & 4 & 8 \\
\hline $\mathrm{C}=\mathrm{P}_{\mathrm{LBB}} \times \mathrm{H}=\mathrm{LIB}$ storage capacity per cycle $[\mathrm{MWh}]$ & 120 & 240 & 480 \\
\hline $\begin{array}{l}S=\text { share of total PV output routed into LIB storage } \\
L I B_{\text {IN }}=P V_{\text {OUT }} \times S\end{array}$ & $7.5 \%$ & $15 \%$ & $30 \%$ \\
\hline $\begin{array}{l}=P V \text { output routed into LIB storage }[\mathrm{MWh}] \\
\text { DIRECT }=\mathrm{PV}_{\text {OUT }}-\mathrm{LIB}_{\text {IN }}\end{array}$ & 306,000 & 612,000 & $1,224,000$ \\
\hline = PV output delivered directly [MWh] & $3,774,000$ & $3,468,000$ & $2,856,000$ \\
\hline$\eta_{s}=$ storage cycle efficiency & $80 \%$ & $80 \%$ & $80 \%$ \\
\hline $\begin{array}{l}\mathrm{LIB}_{\text {OUT }}=\mathrm{LIB}_{\mathrm{IN}} \times \eta_{\mathrm{S}} \\
=\text { electricity delivered by LIB storage [MWh] }\end{array}$ & 244,800 & 489,600 & 979,200 \\
\hline $\mathrm{N}=\mathrm{LIB}_{\mathrm{IN}} / \mathrm{C}=$ number of full charge cycles & 2,550 & 2,550 & 2,550 \\
\hline $\begin{array}{l}\text { SYS }_{\text {OUT }}=\text { DIRECT + LIB OUT } \\
=\text { electricity delivered by PV+storage system [MWh] }\end{array}$ & $4,018,800$ & $3,957,600$ & $3,835,200$ \\
\hline
\end{tabular}




\section{WILEY-VCH}

Table 3. Calculation of total electricity produced by $100 \mathrm{MW}$ PV system over its 30-year service life in high solar irradiation conditions $\left(2,300 \mathrm{kWh} \cdot \mathrm{m}^{-2} \cdot \mathrm{yr}^{-1}\right)$, of the share thereof that is routed into LIB storage, and of the number of full LIB charge cycles that are required over the system's 30 -year lifetime.

\begin{tabular}{|c|c|c|c|}
\hline & $\begin{array}{l}\text { "mininum } \\
\text { storage" } \\
\text { scenario }\end{array}$ & $\begin{array}{l}\text { "baseline" } \\
\text { scenario }\end{array}$ & $\begin{array}{l}\text { "maximum } \\
\text { storage“ } \\
\text { scenario }\end{array}$ \\
\hline $\mathrm{P}_{\mathrm{PV}}=\mathrm{PV}$ installed power $[\mathrm{MW}]$ & 100 & 100 & 100 \\
\hline $\mathrm{T}=\mathrm{PV}$ lifetime $[\mathrm{yr}]$ & 30 & 30 & 30 \\
\hline$P R=P V$ performance ratio & $80 \%$ & $80 \%$ & $80 \%$ \\
\hline Irr = Solar Irradiation $\left[\mathrm{kWh} \mathrm{m}^{-2} \mathrm{yr}^{-1}\right]$ & 2,300 & 2,300 & 2,300 \\
\hline $\begin{array}{l}\mathrm{PV}_{\mathrm{OUT}}=\mathrm{P}_{\mathrm{PV}} \times \operatorname{Irr} \times \mathrm{PR} \times \mathrm{T} \\
=\text { total } \mathrm{PV} \text { output over lifetime }[\mathrm{MWh}]\end{array}$ & $5,520,000$ & $5,520,000$ & $5,520,000$ \\
\hline $\mathrm{P}_{\mathrm{LIB}}=\mathrm{LIB}$ installed maximum power $[\mathrm{MW}]$ & 60 & 60 & 60 \\
\hline H = max. sustained LIB output at max. power [h] & 2 & 4 & 8 \\
\hline $\mathrm{C}=\mathrm{P}_{\mathrm{LIB}} \times \mathrm{H}=\mathrm{LIB}$ storage capacity per cycle $[\mathrm{MWh}]$ & 120 & 240 & 480 \\
\hline $\begin{array}{l}S=\text { share of total PV output routed into LIB storage } \\
L I B_{\mid N}=P V_{\text {OUT }} \times S\end{array}$ & $7.5 \%$ & $15 \%$ & $30 \%$ \\
\hline $\begin{array}{l}=\text { PV output routed into LIB storage }[\mathrm{MWh}] \\
\text { DIRECT }=\mathrm{PV}_{\text {OUT }}-\mathrm{LIB}_{\mathrm{IN}}\end{array}$ & 414,000 & 828,000 & $1,656,000$ \\
\hline$=\mathrm{PV}$ output delivered directly [MWh] & $5,106,000$ & $4,692,000$ & $3,864,000$ \\
\hline$\eta_{s}=$ storage cycle efficiency & $80 \%$ & $80 \%$ & $80 \%$ \\
\hline $\begin{array}{l}\mathrm{LIB}_{\text {OUT }}=\mathrm{LIB}_{\mathrm{IN}} \times \eta_{\mathrm{S}} \\
=\text { electricity delivered by LIB storage [MWh] }\end{array}$ & 331,200 & 662,400 & $1,324,800$ \\
\hline $\mathrm{N}=\mathrm{LIB}_{\mathrm{IN}} / \mathrm{C}=$ number of full charge cycles & 3,450 & 3,450 & 3,450 \\
\hline $\begin{array}{l}\text { SYS }_{\text {OUT }}=\text { DIRECT + LIB OUT } \\
=\text { electricity delivered by PV+storage system [MWh] }\end{array}$ & $5,437,200$ & $5,354,400$ & $5,188,800$ \\
\hline
\end{tabular}




\section{WILEY-VCH}

Table 4. Global Warming Potential (GWP) and Acidification Potential (AP) for electricity produced by the PV system with no energy storage (and without curtailment), vs. by $\mathrm{PV}+$ storage systems under "baseline", "minimum storage" and "maximum storage" conditions. Three alternative LIB battery options are considered: $\mathrm{LMO}^{[17]}$; $\mathrm{NCM}^{[22]}$; LFP ${ }^{[23]}$.

\begin{tabular}{|c|c|c|c|c|}
\hline & PV only & $\begin{array}{l}\text { PV + storage } \\
\text { (min) }\end{array}$ & $\begin{array}{l}\text { PV + storage } \\
\text { (baseline) }\end{array}$ & $\begin{array}{l}\text { PV + storage } \\
\text { (max) }\end{array}$ \\
\hline 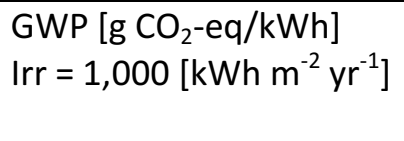 & 62 & $\begin{array}{l}66 \text { (LMO) } \\
72 \text { (NCM) } \\
76 \text { (LFP) }\end{array}$ & $\begin{array}{l}71 \text { (LMO) } \\
82 \text { (NCM) } \\
90 \text { (LFP) }\end{array}$ & $\begin{array}{l}80 \text { (LMO) } \\
103 \text { (NCM) } \\
119 \text { (LFP) }\end{array}$ \\
\hline $\begin{array}{l}\text { GWP }\left[\mathrm{g} \mathrm{CO}_{2} \text {-eq/kWh] }\right. \\
\text { Irr }=1,700\left[\mathrm{kWh} \mathrm{m}^{-2} \mathrm{yr}^{-1}\right]\end{array}$ & 37 & $\begin{array}{l}39 \text { (LMO) } \\
42 \text { (NCM) } \\
45 \text { (LFP) }\end{array}$ & $\begin{array}{l}42 \text { (LMO) } \\
48 \text { (NCM) } \\
53 \text { (LFP) }\end{array}$ & $\begin{array}{l}47 \text { (LMO) } \\
60 \text { (NCM) } \\
70 \text { (LFP) }\end{array}$ \\
\hline 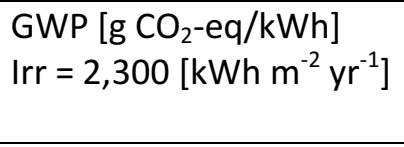 & 27 & $\begin{array}{l}29 \text { (LMO) } \\
31 \text { (NCM) } \\
33 \text { (LFP) } \\
\end{array}$ & $\begin{array}{l}31 \text { (LMO) } \\
36 \text { (NCM) } \\
39 \text { (LFP) }\end{array}$ & $\begin{array}{l}35 \text { (LMO) } \\
45 \text { (NCM) } \\
52 \text { (LFP) }\end{array}$ \\
\hline $\begin{array}{l}\mathrm{AP}\left[\mathrm{g} \mathrm{SO}_{2}-\mathrm{eq} / \mathrm{kWh}\right] \\
\mathrm{Irr}=1,000\left[\mathrm{kWh} \mathrm{m}^{-2} \mathrm{yr}^{-1}\right]\end{array}$ & 0.62 & $\begin{array}{l}0.68 \text { (LMO) } \\
0.73 \text { (NCM) } \\
0.69 \text { (LFP) } \\
\end{array}$ & $\begin{array}{l}0.74 \text { (LMO) } \\
0.84 \text { (NCM) } \\
0.76 \text { (LFP) } \\
\end{array}$ & $\begin{array}{l}0.87 \text { (LMO) } \\
1.06 \text { (NCM) } \\
0.92 \text { (LFP) } \\
\end{array}$ \\
\hline $\begin{array}{l}\text { AP [g SO }- \text {-eq/kWh] } \\
\text { Irr }=1,700\left[\mathrm{kWh} \mathrm{m}^{-2} \mathrm{yr}^{-1}\right]\end{array}$ & 0.37 & $\begin{array}{l}0.40 \text { (LMO) } \\
0.43 \text { (NCM) } \\
0.41 \text { (LFP) }\end{array}$ & $\begin{array}{l}0.44 \text { (LMO) } \\
0.49 \text { (NCM) } \\
0.45 \text { (LFP) }\end{array}$ & $\begin{array}{l}0.51 \text { (LMO) } \\
0.63 \text { (NCM) } \\
0.54 \text { (LFP) } \\
\end{array}$ \\
\hline $\begin{array}{l}\text { AP [g SO }{ }_{2} \text {-eq/kWh] } \\
\text { Irr }=2,300\left[\mathrm{kWh} \mathrm{m}^{-2} \mathrm{yr}^{-1}\right]\end{array}$ & 0.27 & $\begin{array}{l}0.30 \text { (LMO) } \\
0.32 \text { (NCM) } \\
0.30 \text { (LFP) } \\
\end{array}$ & $\begin{array}{l}0.32 \text { (LMO) } \\
0.39 \text { (NCM) } \\
0.33 \text { (LFP) } \\
\end{array}$ & $\begin{array}{l}0.38 \text { (LMO) } \\
0.46 \text { (NCM) } \\
0.40 \text { (LFP) } \\
\end{array}$ \\
\hline
\end{tabular}




\section{WILEY-VCH}

Adding storage to photovoltaics does not detract from its sustainability.

A full LCA is carried out on a utility-scale phtovoltaic (PV) system with lithium-ion battery (LIB) storage. Results indicate that adding electrochemical energy storage to PV does not significantly reduce its advantages in terms of renewability, net energy delivery and carbon emissions, when compared to conventional thermal electricity.

Keyword energy storage

M. Raugei, E. Leccisi, and V. Fthenakis *

Title What are the energy and environmental impacts of adding battery storage to photovoltaics? A generalized life cycle assessment.

\section{ToC figure}

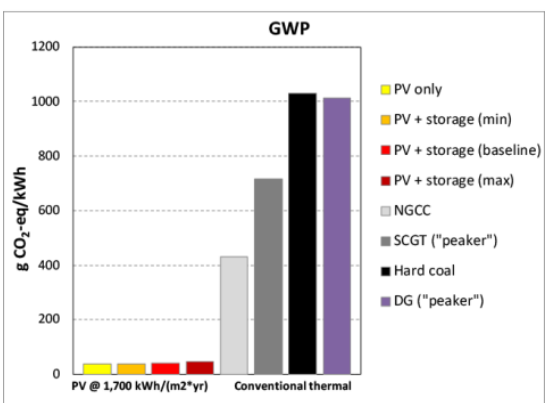




\section{WILEY-VCH}

Copyright WILEY-VCH Verlag GmbH \& Co. KGaA, 69469 Weinheim, Germany, 2018 